\title{
Sustainable Development of Fishermen Settlement Based on Cultural Aspects
}

\author{
Ainun Nurin SHARVINA', Muhammad FAQIH' ${ }^{1}$, Happy Ratna SANTOSA ${ }^{1}$, Arina HAYATI ${ }^{1}$ \\ ${ }^{1}$ Institut Teknologi Sepuluh Nopember (ITS), Department of Architecture, Surabaya, INDONESIA \\ E-mail: sharvina13@mhs.arch.its.ac.id: sharvina.an@gmail.com \\ DOI: 10.24193/JSSP.2018.2.04 \\ https://doi.org/10.24193/JSSP.2018.2.04
}

\begin{abstract}
A B S T RA C T
Most fishermen have low wages and tend to have fewer opportunities to live properly. Consequently, fishermen settlements are often gentrified in urban development, especially in developing countries. Indonesia, one of the developing countries with the longest inhabited coastline, has recently encountered this problem. The sustainable solutions needed to preserve their culture should be implemented while improving the environment. Therefore, it is necessary to develop the concept of sustainable development for fishermen settlement that would be based on local maritime culture. Culture is highlighted because of its roles to drive the surrounding environment for quality improvement in fishermen settlement. To explore sustainable culture especially maritime culture in fishermen context some guiding variables are needed. The aim of this research is to indicate how culture supports the sustainable development concept in fishermen settlement. The method used in this research is exploring theories by descriptive qualitative analysis. By using the theory of culture in sustainable development, the paper assessed maritime culture and settlement. The result of this paper is that culture is a guiding variable in the sustainable development of fishermen settlement, which consists of five layers of cultural aspects, detailed in the maritime culture. This variable can be used in further research on fishermen settlement based on cultural aspects.
\end{abstract}

\section{INTRODUCTION}

The term sustainable development first appeared in the Brundtland report, and was defined as "development that meets the needs of the present without compromising the ability of future generations to meet their own needs" [1]. In order to achieve that goal, the report then introduced three pillars of sustainable development consisting of economic, ecological and social aspects [2], [3], [4]. Sustainable development with three pillars provides a more tangible concept as compared to previous development concepts. The introduction of the three pillars of sustainable development improves public awareness on sustainable development. However, the concept of three pillars sets some limits to the basic definition of sustainable development. On the other hand, the concept must be adapted to cities or countries, and the urban development pattern must be based on the traditional and local hierarchy of culture that needs to be addressed [5]. Furthermore, findings revealed that there is social degradation in environmental development approach practice [6], therefore sociocultural patterns must be highlighted as one important aspect in sustainable development [7]. Social and cultural aspects are important pillars in sustainable development because they are closely related to human expression which further defines the sustainable development's goals [8].

This research asserts that the cultural pillar should be distinctive from the social pillar. It means that culture should become the fourth pillar that 
supports sustainable development besides economy and ecology. The relationship between the culture pillar and the other three pillars does not seem to have an adequate explanation in the literature. Still, Dessein et al (2015) highlighted that there are three cultural roles in sustainable development: culture in sustainability, culture for sustainability and culture as a basis of sustainability [9].

The culture pillar is important as the basis of development because it is associated with the life of every human being [10]. Every society within a particular region has a different culture, hence the cultural consideration in the implementation of sustainable development would not be the same in each sub-region [11], [12].

Culture-based development has been implemented in various parts of the world, including Indonesia [9]. However, sustainable development based on the culture pillar has not been explored extensively, especially in an archipelagic state such as Indonesia. Then, the question is how culture influences sustainable development in this archipelago. This should be clearly stated, because the characteristics of coastal society are different. The inhabitants of coastal settlements have adapted to marine oriented livelihoods; therefore their income depends on the utilization of marine and coastal resources. Thus, it is clear that their behaviour is significantly affected by their environment, which is marine livelihood.

Some of the previous studies on fishermen settlement were based on their sustainable development, but they just focused on one pillar [13], [14], [15], whilst few others either not included culture at all or focused a little on the development of fishermen settlement with culture as a base. It has been discussed about the maritime culture indicators that can be assessed on fishermen settlement in any contexts and places. The results of a previous study reveal that indicators of maritime culture consist of aspects and factors, comparing theories using qualitative methods, yet not mentioning the position of culture in the sustainable development theory [16]. Our paper will debate on the cultural aspects in sustainable development, maritime culture as a fishermen's livelihood and the types of cultural aspects that could be considered in archipelago country, especially in fishermen settlement.

\section{THEORY AND METHODOLOGY}

The purpose of this research is to deepen and distinguish the maritime culture in fishermen settlement with research limited to secondary data, study that is based on sustainable development, maritime culture, and housing theory. The review of literature resulted in an analysis of the theory of sustainable development based on maritime culture. The stages of elaboration consisted, firstly, in debating the relationship between sustainable development and culture, and secondly, the relationship between sustainable development and settlements. The snowball sampling method was used by exploring the theory through the secondary data related to the local culture context. The analysis method used was descriptive qualitative.

\subsection{Sustainable development and culture}

There are three roles of culture in sustainable development, namely: culture in sustainability, culture for sustainability as continuous action in encouraging sustainable development and culture as a basis of sustainability [9], all three of them being detailed in Figure 1. The definition of culture in sustainability is culture as a form of capital. The definition of culture for sustainability is a way of life and its customs, and culture as the basic policy is culture as semiosis, using culture as the basis in manufacturing a new policy.

\section{Culture in Sustainable Development}

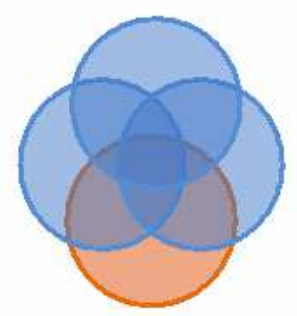

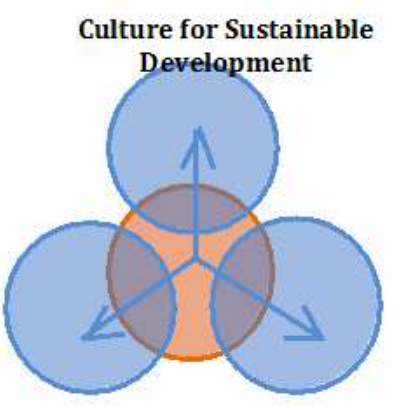

Culture as Sustainable Development

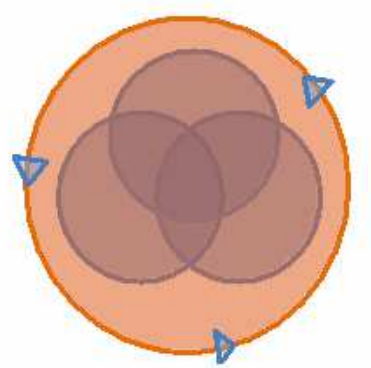

Fig. 1. The roles of culture [9].

The contribution of local culture to sustainable development can be described as follows: first, local culture as identity, as contributor to quality of life and as container of tradition. The vitality of the local culture that has evolved through acculturation and growth is expected. Acculturation welcomes other cultures with kindness. Second, local culture could contribute as a source of inspiration for social harmony and peace. Third, local culture provides knowledge about the human residents of the neighbourhood. Fourth, 
participation in the economy and politics needs to cover all aspects, including culture. Fifth, local culture can contribute as an intermediary to the core of economic development. And lastly, local culture could contribute as social science resource in human civilization [17].

Previously, discussing culture as fourth pillar in the structure of sustainable development, culture has been promoted from being a component of the social pillar to the status of independent pillar. But at this moment, the role of culture is undervalued in sustainable development theory. The role of culture has been limitedly used as a modality and product of sustainable development. In fact, the role of culture is as a base or a root in sustainable development and in implementing development approaches.

Generally, culture refers to the beliefs, perceptions, values and norms within a society. The term culture is used to indicate cognition, feelings, and behaviours between groups within the same habitat [18]. Culture can be defined as matters related to the mind and intellect. Culture has a perceivable form that can be seen and felt by senses. It is a whole system of ideas, actions, and the work of man in society. From this statement we can conclude that culture includes three systems, namely: the cultural system, the social system and the physical cultural system [19]. First, culture is cultivated through families, especially during childhood as a part of education. Second, culture involves values or norms in a community, and beliefs that involve forging the mentality and behaviour of the community members. Third, culture is reflected in an object and the physical environment such as home design, layout of settlements and public buildings.

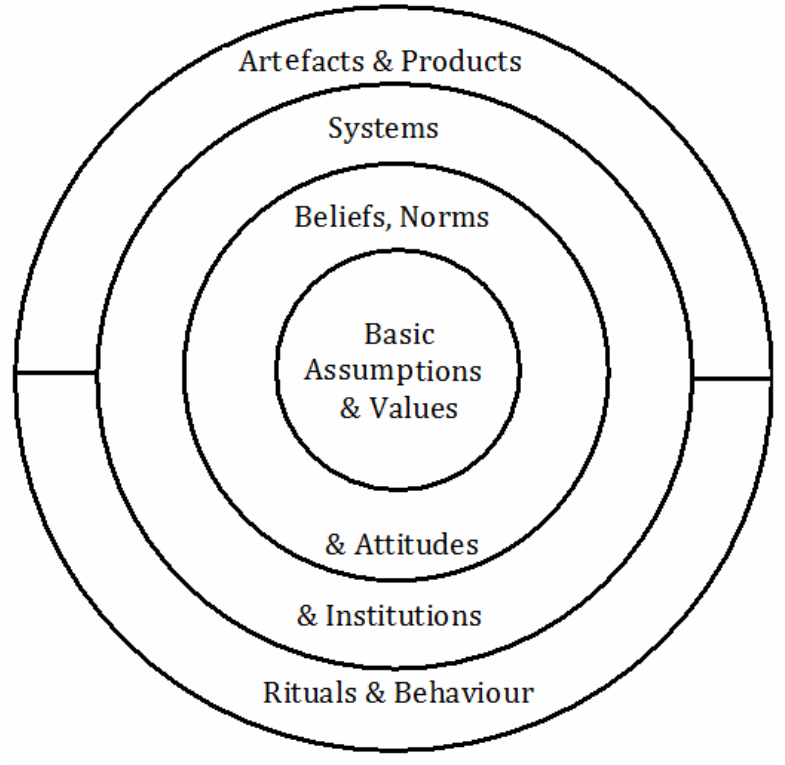

Fig. 2. The model of cultural layers [20].

Oatey (2000) suggested the depth of differences in culture in a model of four layers. The core consists of assumptions and values, the next layer includes attitudes, beliefs, social customs, and then the following layer consists of systems and institutions, whilst the last layer consists of artefacts and products, behaviours and rituals [20]. This model is illustrated in Figure 2. This model significantly improved the Koentjaraningrat theories on culture. Koentjaraningrat (1992) just revealed three layers of culture [19], while Spencer-Oatey added one more layer that manifested in artefacts products and rituals and behaviour [21].

Since, culture is blurred between the basic assumptions and values, life orientation, beliefs, policies, procedures and behavioural habits shared by a group of people, the cultural layers need to be explained and interpreted by each member of the group [21]. Considering this framework, our study uses these cultural aspects as the analytical model for the sustainable development of settlements on islands.

\subsection{Sustainable development and settlements}

The relationship between sustainable development and settlements depends on the local contexts. Sustainability assessment cannot be applied in all conditions [12]. Whether it is in the neighbourhoods, formal settlement, informal settlement, urban, rural, cities or coastal, each location has its own characteristics.

Human settlement will go well if associated with several elements: nature, man (human), society (social life), shell (space), and networks (relationships) [22]. Another settlement theory, defines settlement as something that is closely related to the concepts of residence or home. Turner (1976) explained that house has two meanings, namely; (1) house as a noun or house as a product, and (2) the second is housing as a verb or house as a process [23]. House as a noun indicates dwellings (house and land) as forms of production or commodities. House as a verb denotes a process and human activities occurring in the construction as well as during the process of inhabiting it.

From both opinions stated above, the human settlement is not only seen as a physical form, but also as a process of settlement. Settlement as a process is closely related to human activity. Human activity is influenced by the ideas or thoughts of others, while each opinion is influenced by their culture. It is argued that culture is an aspect that influences a person in choosing a home [23]. However, this statement is implicitly expressed. A person moves into a rented house because of the influence of economic circumstances, without considering that this process is also influenced by culture.

Regarding the link between culture and settlements, culture can be interpreted as people's beliefs that are reflected in the daily activities. It can be felt and seen in a physical form that is manifested in the form of settlements or shape of the buildings. Culture is closely related to the built environment that it created. The relationship between people and environment 
could not only be seen from buildings alone; but if people were merged with the whole building and environment around them, we should observe what is commonly called the built environment. Definitions of culture in settlements or at the microscale can be called occupancy culture and it depends on the system setting. System setting contains system activity and behaviour in public life [24]. Thus, culture could be seen in activities and lifestyle. The scope of this built environment is divided into micro, meso and macro systems. In the fishermen settlement, the macro scope is the collection of several residences in relation to several public facilities. The meso scope is the relationship between one dwelling and the other dwellings. The last, the micro scope represents a single building occupied by the fisherman. In line with that, architecture (building) is a cultural product [25]. Therefore, based on the argument above, it can be concluded that there is a relationship between the building's shape and the culture of the inhabitant.

\section{RESULTS AND DISCUSSION}

Results and discussions cover the fishermen settlement and maritime culture and the last part represents the debate on this matter in the context of Indonesia.

\subsection{Fishermen settlement and the maritime culture}

Most of the fishermen settlements in Indonesia are located next to water or sea, which supports their marine and fishery functions [26]. The fishermen settlements in Indonesia are located along the coastline as well as along river banks and inland lakes [27].

Fishermen settlements in Indonesia have various problems such as irregular land use, decreased physical quality related to facilities and infrastructure, housings, and slum fishermen settlements [13], [14], [28], [29], [30]. Additionally, fishermen settlements in coastal area also have to deal with the issue of climate change resulting in increased sea water level on the coastal area [31], [32]. Thus, various countermeasures and concepts have emerged to overcome the climate change by the physical rearrangement of settlements [33], [34], [35].

Several researches related to the adaptation of fishermen settlements were conducted through physical and non-physical structuring approaches. Some researches revealed ways to solve problems through a cultural approach to the society. One of the researches about culture in resettlement in fishermen settlement was done with a maritime culture approach, but that research was specific to fishermen settlements on large islands [14]. The particularity of a large island is the numerous ways of access to the location by land, sea and air, while small islands could only be reached through sea. In short, large islands are easier to reach than small islands.

Fishermen settlements in Indonesia have been ideally located close to the waterfront, which have supported resident's livelihoods with socio-economic activities that were oriented to water and land. These characteristics of housing and settlement based on location are of two kinds, namely: above the water and on the land [36]. The buildings in fishermen settlements located above-water tend to be dense and rundown. The buildings' orientation tends to face the water and also to have an irregular and organic cluster pattern. The fishermen house's form, built on the land, and the location near the coastal area are considered functional and accessibility aspects. From the architectural perspective, buildings in the coastal areas are distinguished by: building on the land, elevated building on the land, elevated buildings on stilts over the water and building on rafts on the water (now rare). The architectural forms of the buildings were shaped according to the traditional rules and modern technology, in accordance with the cultural and ethnic backgrounds.

The housing design in the coastal regions all over Indonesia is quite diverse. In some areas such as Sumatra, Java, Bali, and Nusa Tenggara, homes are mostly found as detached houses. Some use a permanent structure, while some others use nonpermanent or informal houses, and also a combination of both kinds of structures. Housings in coastal area that are built on the land are common in Jeneponto, Bulukumba, Bantaeng and in Bangkalan Madura. Fishermen housings over the water can be found in Pontap (Palopo), Bajo, and Bontang Kuala.

Fishermen have knowledge of how to catch fish, making nets, shipbuilding and knowledge of seasons, winds, tides, currents, astronomy and direction [37]. They also know about the manufacture and the type of boat that is suitable for fishing in their areas. Even, some superstition rituals are performed during boatbuilding and open-air seasons every year. When someone dies at sea, people will give a marker on the scene with a white shirt, so that other fishermen would not cross that area.

Maritime culture is a system, an idea, behaviour, physical facilities and infrastructure used by the society to utilize marine resources for their livelihood. The nature and characteristics of maritime culture include maritime culture systems, institutional systems and maritime technology. Maritime culture systems include the knowledge, values, and norms, with respect to harvesting marine resources. Fishing knowledge systems include knowledge about the marine commodities with high economic value, knowledge of the fish location and the fish nesting, 
knowledge of the seasons, knowledge of the signs (in the sea, land, sky, or astrology) and knowledge of the socio-cultural environment. The institutional system is maintained by the maritime community as the working group system managing the ownership and controlling the marine areas. The last nature and characteristic of maritime culture is the maritime technology, which is associated with the tools and fishing techniques.

The characteristics of the coastal or fishing communities can be derived from some perspectives, namely: knowledge systems, belief systems, distinctive gender tasks (women's role) [38], social structure, and social position of fishermen. The system includes an understanding of the knowledge of fishing techniques, ocean depths, currents, weather markers and direction, tide, boat maintenance techniques. A fisherman's belief is related to the belief that the sea has magical powers that must be avoided by doing necessary activities or certain rituals related to marine safety. These ritual activities are related to the inclusion of religious influence. The role of women is to continue the fishing activities such as processing the fish. The classification of social position in fishermen communities is cultural, structural, and political.

The basis of maritime tradition could be seen from the climate and monsoon winds, society and culture (origins, language, belief, culture and work ethic, settlement structure) [39], as it can be seen from the seafarers' solidarity with their boat. Tradition also includes how to build a boat, a voyager community, knowledge of space (islands, corals, winds, ghosts of the sea and stars), greener solidarity (related to tradition in sailing, boat lending, venture capital and profit sharing, life in a boat) and discussion of the space of the ocean (the imaginary boundary of the sailor and the territorial boundary of the state).

Fishermen's technological capabilities (fishing tools and fleets), market orientation and characteristics of product are divided into four levels, namely: peasant fisher or traditional fishing, post-peasant fisher, commercial and industrial fisher [40]. Peasant fisher or traditional fisher is mostly oriented to self-sufficiency.
The catch is sold only for the fulfilment of daily needs, using traditional fishing tools and a boat or canoe with paddles or sail. Post-peasant fishermen are described as more advanced fishermen with motorboat technology. The fisherman at this level is much more marketoriented than the traditional or peasant fisher. Commercial fishermen are profit-oriented. The business scale is enlarged with some paid workers. Industrial fisherman, in addition to using adapted technology, also uses a sophisticated vessel in a large number of fleets. It involves several crew members to be able to do more complex work.

\subsection{Culture in the context of fishermen settlement in the Indonesian archipelago}

The Indonesian fishermen culture is highly influenced by the geographical and climate condition, and also by the fisherman working ethos. Furthermore, Indonesia conditions that consists of several specific characteristics of fishermen settlement, implies that culture is different depending on the area under study, and if three main reasons are considered.

Firstly, the settlement are distributed on 17,504 islands and a sea area of 5.9 million $\mathrm{km}^{2}, 3.2$ million $\mathrm{km}^{2}$ of territorial sea and 2.7 million $\mathrm{km}^{2}$ of exclusively economic zones [41] and Indonesia with the longest coastline in the world, holds $18.4 \%$ of the world's coastlines [42] causing many Indonesian people to live in coastal areas. Secondly, Indonesia tropical monsoon climate with dry season (locally known as the west wind seasons) and wet season (locally known as the east wind seasons) develop the fisherman-working season that varies according to the geographical location. Thirdly, most of the fishermen settlements in Indonesia are informal settlements [43] that were commonly built in community by mutual cooperation.

Based on the discussion on fishermen settlement and maritime culture in Indonesia, some variables could be formulated (Table 1) to reveal contributions of culture to sustainable development, which can be linked to maritime culture.

Table 1. Variable of culture in sustainable development of fishermen settlement.

\begin{tabular}{|l|l|l|l|}
\hline $\begin{array}{l}\text { Contribution of culture to } \\
\text { sustainable development }\end{array}$ & $\begin{array}{c}\text { Cultural } \\
\text { aspects }\end{array}$ & \multicolumn{1}{|c|}{ Maritime culture } & \multicolumn{1}{c|}{ Variables } \\
\hline $\begin{array}{l}\text { Local cultures provide } \\
\text { knowledge about the human } \\
\text { residents of the } \\
\text { neighbourhood }\end{array}$ & $\begin{array}{l}\text { Basic } \\
\text { assumptions and } \\
\text { values }\end{array}$ & $\begin{array}{l}\text { Basic knowledge about } \\
\text { the sea, fisheries, } \\
\text { astronomy and daily } \\
\text { activities of fishermen }\end{array}$ & $\begin{array}{l}\text { Fish nesting place } \\
\text { Time or season to catch fish } \\
\text { Astronomy (sign on land and at sea, moon, sky) } \\
\text { Wind direction and weather changes } \\
\text { Characteristics of the ocean, coast and coral. } \\
\text { Ocean navigation } \\
\text { Understanding of the depth of the waters and the } \\
\text { ocean currents. }\end{array}$ \\
\hline
\end{tabular}




\begin{tabular}{|c|c|c|c|}
\hline & & Value and principles & $\begin{array}{l}\text { Basic principles } \\
\text { In the fisherman (the meaning of sea in everyday } \\
\text { life) } \\
\text { Customary law or rules in the life of fishermen or } \\
\text { work ethic }\end{array}$ \\
\hline & & $\begin{array}{l}\text { Symbol of } \\
\text { communication }\end{array}$ & $\begin{array}{l}\text { Local language } \\
\text { Sign related tradition }\end{array}$ \\
\hline \multirow{3}{*}{$\begin{array}{l}\text { Local culture is a source of } \\
\text { inspiration for social } \\
\text { harmony and peace }\end{array}$} & \multirow{3}{*}{$\begin{array}{l}\text { Beliefs, norms, } \\
\text { and attitudes }\end{array}$} & Belief in religion & $\begin{array}{l}\text { Religious view in daily life } \\
\text { Use of religion as problem solving }\end{array}$ \\
\hline & & $\begin{array}{l}\text { Belief in myths or } \\
\text { supernatural things in } \\
\text { sea or coastal land }\end{array}$ & Myths about sea spirits \\
\hline & & Space of the ocean & $\begin{array}{l}\text { The imaginary boundary of the sailor and the } \\
\text { territorial boundary of the state }\end{array}$ \\
\hline \multirow{4}{*}{$\begin{array}{l}\text { Participation in the economy } \\
\text { and politics needs all aspects } \\
\text { including culture }\end{array}$} & \multirow{4}{*}{$\begin{array}{l}\text { Systems and } \\
\text { institutions }\end{array}$} & Social position & $\begin{array}{l}\text { Based on fishing gear } \\
\text { Based on fishery technology }\end{array}$ \\
\hline & & Economic position & $\begin{array}{l}\text { Based on boat asset } \\
\text { Based on commodity of catch or haul }\end{array}$ \\
\hline & & Structural and politics & Fishermen's institution based on kinship or politics \\
\hline & & Cultural position & $\begin{array}{l}\text { Fishermen's institution based on knowledge about } \\
\text { tradition culture and religion }\end{array}$ \\
\hline \multirow{5}{*}{$\begin{array}{l}\text { The local culture as identity, } \\
\text { contributor to quality of life } \\
\text { and contains tradition }\end{array}$} & \multirow{5}{*}{$\begin{array}{l}\text { Rituals and } \\
\text { behaviour }\end{array}$} & $\begin{array}{l}\text { Fishermen's daily } \\
\text { activities }\end{array}$ & $\begin{array}{l}\text { Preparation for fishing } \\
\text { Fishing practice } \\
\text { Fishing cycle }\end{array}$ \\
\hline & & $\begin{array}{l}\text { Roles of men and } \\
\text { women }\end{array}$ & $\begin{array}{l}\text { Task at sea, coastal, home and settlement or } \\
\text { neighbourhood }\end{array}$ \\
\hline & & $\begin{array}{l}\text { Fisherman housing } \\
\text { activities }\end{array}$ & $\begin{array}{l}\text { All daily activities (sleep, eat, cook, pray, bath) } \\
\text { Fish process activity (catch, cleaning, drying, salting } \\
\text { and selling) } \\
\text { Process to make fishing medium (make a net or boat } \\
\text { construction) }\end{array}$ \\
\hline & & $\begin{array}{l}\text { Fisherman's settlement } \\
\text { activities }\end{array}$ & $\begin{array}{l}\text { Religious ceremony } \\
\text { Culture of open sea ceremony } \\
\text { Culture of boat } \\
\text { construction ceremony }\end{array}$ \\
\hline & & Society participation & $\begin{array}{l}\text { Participation in neighbourhood } \\
\text { Participation at sea } \\
\text { Participation in every activity of village } \\
\text { Solidarity }\end{array}$ \\
\hline \multirow{6}{*}{$\begin{array}{l}\text { Local culture as an } \\
\text { intermediary for the heart of } \\
\text { economic development and, } \\
\text { local culture as a source of } \\
\text { human civilization }\end{array}$} & \multirow{6}{*}{$\begin{array}{l}\text { Artefacts and } \\
\text { products }\end{array}$} & Fishing technology & Type and capacities of fishing tackles \\
\hline & & Motorization technology & $\begin{array}{l}\text { Type and boat capacity, boat making and } \\
\text { maintenance }\end{array}$ \\
\hline & & $\begin{array}{l}\text { Fish processing } \\
\text { technology }\end{array}$ & $\begin{array}{l}\text { Fish processing methods, cultivation, technique and } \\
\text { equipment }\end{array}$ \\
\hline & & $\begin{array}{l}\text { Fisherman's traditional } \\
\text { culture }\end{array}$ & $\begin{array}{l}\text { Local product food, arts (dance, music, song, games, } \\
\text { poems, ceremonies) }\end{array}$ \\
\hline & & Fishermen housing & $\begin{array}{l}\text { Structure and material } \\
\text { Shape } \\
\text { Space organisation } \\
\text { Direction }\end{array}$ \\
\hline & & Fishermen settlement & $\begin{array}{l}\text { House location (base of kinship or other } \\
\text { relationship) } \\
\text { Road systems } \\
\text { Housing infrastructure: Physical (electricity, water, } \\
\text { sanitation, drainage, waste management) and non } \\
\text { physical (social, health, religion, economic and } \\
\text { culture facilities). }\end{array}$ \\
\hline
\end{tabular}

Culture can be traced through five cultural layers. Each layer is linked to maritime culture that is detailed in variables (the right column in Table 1). The first layer of local culture provides knowledge about the human residents of the neighbourhood (second column, first row, Table 1). The environment can be identified through about the grasp of the values of the local community. The basic assumptions and values consist 
of (1) basic knowledge about the sea, fisheries, astronomy and daily activities of fishermen, (2) values and principles and (3) symbols of communication. The basis of maritime cultural aspects is not detailed, but should be specified. Variables that include basic knowledge are: high value marine biota, fish nesting places, time or season to catch fish, astronomy (signs on land and at sea, moon, sky), wind direction and weather changes, characteristics of the ocean, coast and coral and ocean navigation. The values and principles comprise the basic principles of fishermen, which are related to the meaning of the sea in everyday life and customary law or rules in the life of fishermen or their work ethics. Language and traditional symbols can enable communication between them.

The second layer of culture is about beliefs, norms, attitudes (second column, second row, Table 1). It can be a source inspiration for social harmony and peace. Beliefs in the lives of fishermen are associated with their dependence on the nature of the sea. They are very respectful of the sea and The Creator (God), as reflected in the religious views in daily life, the use of religion in problem solving, and their belief in the myth of the sea and space of the ocean.

One way to achieve sustainable development is by increasing participation in the economy and politics through culture. This is in line with the third cultural layer, of systems and institutions (second column, third row). Systems and institutions are formed from society, economy and culture. One's social position is closely related to the economy, while the cultural position is more assembled with tradition, beliefs and religion.

The fourth layer of local culture (second column, fourth row, Table 1) can contribute to a quality of life that consists of traditions, attached to the habits of everyday of life and some rituals like the fishermen's preparation for fishing practice and the fishing cycle. The roles of men and women in daily life affect the place of behaviour, in all activities (daily, weekly, monthly and yearly) and a place of activity (dwelling and settlement).

Local culture is at the heart of economic development and the source of human civilization through artefacts and products. The fifth layer (second column, fifth row, Table 1) is related to the fisherman's traditional culture, fishing technology, housing and settlement. Fisherman's housing can identify with structure and material, shape, space organisation and direction. Fishermen settlement is all about location (the base of kinship or other relationships), road systems, infrastructure and non physical aspects.

\section{CONCLUSION AND FUTURE RESEARCH}

The role of culture in sustainable development is very important. Culture contributes in several ways that can be explored through five layers, which are what constitutes a process of culture. This study has proposed the identification of maritime cultural variables from five layers in the fishermen settlement through descriptive qualitative method based on literature review. The study shows that defining every single layer is necessary to determine the structural system of maritime culture. The results reveal that spiritual beliefs, related both to religion and tradition, and fishermen's institution are manifested in fishermen's behaviour and spatial form of settlements.

The result of this research hopefully becomes the guidance to explore the sustainable maritime culture in the archipelago state, especially Indonesia. Also, every place has its own culture. The result of exploring the maritime culture hopefully could be considered as a basic principle to build a sustainable fishermen settlement, which could farther create and preserve the sustainable settlement without neglecting the maritime culture.

\section{REFERENCE}

[1] WCED (1987), Report of the World Commission on Environment and Development: Our Common Future. Oxford University Press, New York. Available online at: http://www.un-documents.net/our-common-future.pdf.

[2] Dovers, S. R., Lindenmayer, D. B. (1997), Managing the environment: rhetoric, policy and reality, Aust. J. Public Administration, vol. 5, pp. 6580. DOI: $10.1111 /$ j.1467-8500.1997.tbo1547.x

[3] Charles, A. T. (2001), Sustainable Fishery System. Blackwell Science Ltd, Oxford. DOI: 10.1023/A\%3A1021326610318.

[4] Masroori, B. (2011), Fisheries Sustainability and Sustainable Development. In: Journal of Fisheries and Aquatic Science, vol. 6, issue 1, pp. 1-21, Sultanate of Oman. DOI: 10.3923/jfas.2011.1.21

[5] Lethbridge, D. (1993), Does Sustainable Development Depend on Competition or Collaboration? The Case of Darwin versus Gaia. In: Sustainable Development, vol. 1, no. 2, pp. 30-39. DOI: $10.1002 / \mathrm{sd} .3460010208$.

[6] Harris, J. M. (2000), Basic Principles of Sustainable Development, Global Development and Environment Institute, Working Paper oo-04. Available online at: http://ase.tufts.edu/gdae/publications/ working_papers/Sustainable\%2oDevelopment.pdf

[7] Cernea, M. M. (1993), Culture and Organization: the Social Sustainability of Induced Development. In: Sustainable Development, vol. 1, no. 2, pp. 18-29. DOI: 10.1002/sd.3460010207

[8] Hawkes, J. (2001), The Fourth Pillar of Sustainability: Culture's essential role in public planning, Last accessed: February, 12, 2017. Available online: http://www.culturaldevelopment.net.au/community/Dow nloads/HawkesJon(2001)TheFourthPillarOfSustainability .pdf 
[9] Dessein, J., Soini, K., Fairclough, G., Horlings, L. G. (Eds.) (2015), Culture in, for and as Sustainable Development, Conclusions from the COST Action IS1007 Investigating Cultural Sustainability. University of Jyväskylä. Last accessed: Nov, 24, 2017. Available online at: http://www.culturalsustainability. eu/conclusions.pdf

[10] Soini, K., Dessein, J. (2016), CultureSustainability Relation: Towards a Conceptual Framework, Sustainability 2016, 8, 167; doi:10.339o/su8020167, Available online at: www.mdpi.com/journal/ sustainability. Last accessed: Dec, 10, 2017. DOI:10.3390

[11] Delendi, M. L. (2017), Sustainable Living Model. In: International Journal of Sustainable Development and Planning, vol. 12, issue 4, pp. 772-779. DOI: 10.2495/SDP-V12-N4-772-779. Last accessed: April, 15, 2017.

[12] Doussard, C. (2017), Assessment of Sustainable Neighbourhoods: from Standards to Cultural Practices. In: International Journal of Sustainable Development and Planning, vol. 12, issue 3, pp. 368378. DOI: 10.2495/SDP-V12-N3-368-378.

[13] Pramesti, P. L. P., Soemarno, I., Defiana, I. (2015), Arrangement Concept of Fishermen's Settlement in Wonorejo Surabaya to Support The Mangrove Ecotourism. In: International Journal of Engineering Research \& Technology (IJERT), ISSN: 2278-0181, vol. 4 Issue 06, June-2015. pp. 782-790. Last accessed: Jan, 17, 2018.

[14] Dewi, E. K,. Santosa, H. R,. Defiana, I. (2015), Sustainable Fisherman settlement Arrangement Concept for Improving Slum Area in Bangkalan Regency. In: International Journal of Engineering Research \& Technology (IJERT), vol. 4 Issue 06, June-2015. pp: 712-719. Last accessed: Jan, 17, 2018.

[15] UN-OHRLLS (2015), Small Island Developing States in Number: Climate Change Edition, 2015. Available on;ine at: http://unohrlls.org/customcontent/uploads/2015/12/SIDS-IN-NUMBERS-

CLIMATE-CHANGE-EDITION_2015.pdf

[16] Rahmadaniyati, D., Faqih, M., Septanti, D. (2017), Maritime Culture Indicators for the Development of Fishermen's Settlement. In: International Journal of Innovative Science and Research Technology, vol. 2, Issue 6, June - 2017. Last accessed: August, 3, 2017. https://www.scribd.com/ document /353933999/Maritime-Culture-Indicatorsfor-the-Development-of-Fishermen-s-Settlement

[17] Duxbury, N., Hosagrahar, J., Pascual, J. (2016), Culture 21: Agenda 21 for culture. Why must culture be at the heart of sustainable urban development?, United Cities and Local Government. http://www.agenda21culture.net/sites/default/files/file s/documents/en/culture_sd_cities_web.pdf. Last accessed: Dec, 9, 2018.
[18] Altman, I., Chemers, M. (1984). Culture and Environment, Brooks Cole. Monterey, California.

[19] Koentjaraningrat (1992), Kebudayaan, Mentalitas dan Pembangunan [Culture, Mentality and Development]. Gramedia Pustaka Utama, Jakarta.

[20] Spencer-Oatey, H. (2000), Rapport management: a framework for analysis. In: $\mathrm{H}$. Spencer-Oatey (ed) Culturally Speaking. Managing Rapport through Talk across Cultures. London: Continuum, pp. 11-46.

[21] Spencer-Oatey, H. (2012), What is Culture? A Compilation of Quotations. GlobalPAD Core Concepts. Available at GlobalPAD Open House. Last accessed: May, 20, 2017. Available online at: https://warwick. ac.uk/fac/soc/al/globalpad/openhouse/interculturalski lls/global_pad_-_what_is_culture.pdf

[22] Doxiadis, C. A. (1977), Ecology and Ekistics. Westview Environmental Studies, Westview Press.

[23] Turner, J. F. C. (1976), Housing by People. Towards Autonomy in Building Environments. Marion Boyars Publishers Ltd., London, Great Britain

[24] Rapoport, A. (2005), Culture, Architecture, and Design, Locke Science Publishing Company, Inc, Chicago, USA.

[25] Fallah, S. N., Khalili, A., Rasdi, M. T. bin M. (2015), Privacy as a cultural value in traditional Iranian housing; Lessons for modern iranian high density vertical development (HDVD) housing. In: Archnet-IJAR, vol. 9, no. 1, pp. 198-216. http://www.archnet-ijar.net/index.php/IJAR/article/ viewFile/324/pdf_45.

[27] Peraturan Menteri Negara Perumahan Rakyat Republik Indonesia Nomor 14/Permen/M/20o6. (2006), Tentang Penyelenggaraan Perumahan Kawasan Khusus. Menteri Negara Perumahan Rakyat, Indonesia. (Regulation No. 14 of the State Ministry of Public Housing of the Republic of Indonesia.] (in Indonesian).

[28] Umbara, A. R. (2003), Kajian Relokasi Permukiman Kumuh Nelayan ke Rumah Susun Kedaung Kelurahan Sukamaju/Bandar Lampung [Study on the Relocation of Slum Settlements to Kedaung Flats. The case of Sukamaju Subdistrict/Bandar Lampung village], Thesis of Magister Study Program, University of Diponegoro, Semarang.

[29] Susi, Theresia, Sutrisno, H. (2008), Permukiman di Atas Air dan Lingkungan Aquatik Sebuah Konsep Pembangunan Berkelanjutan [Settlements on Water and Aquatic Environment - a Concept of Sustainable Development]. Proceedings, National Seminar on Eco Urban Design, Potential and Challenges, of Future Urban Planning in Indonesia, Department of Urban and Regional Planning, University of Diponegoro. Semarang. Available online at: https://core.ac.uk/download/pdf/11736775.pdf? repositoryId $=379$

[30] Hasanuddin, Nurul L., Novesty Noor, Happy, R. Santosa (2013), Is It Possible To 
Eradicate Poverty In The Fishermen Village? In: International Journal Of Environmental Sciences vol. 4, no. 2, 2013. Last accessed: Jan, 17, 2018. Available online at: https://core.ac.uk/download/pdf/11736775. pdf.

[31] Dahliani, et al. (2015), Settlement Renewal Strategies Based on Physical and Non-Physical Characteristics in Kalisari Fishermen Settlement, Surabaya-Indonesia. In: Humanities and Social Sciences. vol. 3, no. 3, pp. 102-110. doi: 10.11648/j.hss.20150303.11. Last accessed: Feb, 24, 2018.

[32] Soemarno, I, Faqih, M., Setiawan, W. (2013), Climate Change Study on Coastal Settlements and Traditional Architecture in Madura Island, World Building Congress 2013, Australia 5-9 May 2013. Source: http://www.irbnet.de/daten/iconda/CIB_DC 27138.pdf Last accessed: Jan, 17, 2018.

[32] Setioko, B., Pandelaki, E. E., Murtini, T. W. (2013), Towards Sustainable Urban Growth: The Unaffected Fisherman Settlement Setting (with Case Study Semarang Coastal Area). In: Procedia Environmental Sciences, vol. 17 pp: 401-407. DOI: 10.1016/j.proenv.2013.02.053. Last accessed: Jan, 17, 2018.

[33] Pramono, Y. Setyo (2010), Pengembangan Kampung Wisata Nelayan Puger Kabupaten Jember [Development of Tourism in Fishermen Village, Puger Jember Regency]. National Conference Ftsp-Itn, Malang, 15 July 2010, pp: 1-10. Last accessed: Jan, 17. 2018. Available online at: https://www.scribd.com/ doc/35156599/PENGEMBANGAN-KAMPUNGWISATA-NELAYAN-PUGER-KABUPATEN-JEMBER

[34] Ristianti, N. S. (2015), Pengembangan Konsep Wisata Apung Kampung Nelayan Pesisir Balikpapan [Development of floating tourism concept in coastal settlement Balikpapan]. In: Jurnal Ruang, vol. 1, no. 1, pp: 31-40. DOI: http://dx.doi.org/10.14710/ruang.1.4. 31-40. Last accessed: Jan, 17, 2018.

[35] Paputungan, M. S., Warouw, F., Tilaar, S. (2014), Arahan Pengembangan Permukiman Nelayan Berbasis Ekowisata (Studi Kasus: Pesisir Pantai Malalayang, Kelurahan Malalayang Satu Dan Malalayang Satu Timur, Kecamatan Malalayang, Kota Manado [Fishermen Settlement Development based on Ecotourism (Case Study: Malalayng Coastal, Malalayang satu and east Malalayang Sub-district)]. In:
Sabua, vol. 6, no. 3, pp: 341 - 349, Available online at: https://ejournal.unsrat.ac.id/index.php/SABUA/article /view/6061. Last accessed: Feb, 24, 2018.

[36] Amri, N. I. (2014), Laporan Penulisan Buku Ajar: Mata Kuliah Perumahan Pesisir [Course of Coastal Housing] (in Indonesian). Makassar.

[37] Barnes, R. H. (1996), Sea Hunters of Indonesia: Fishers and Weavers from Lamalera. Clarendon Press, Oxford.

[38] Lampe, M. (2003), Budaya Bahari dalam Konteks Global dan Modern (Kasus komuniti-komuniti Nelayan di Indonesia), [Maritime Culture in Global and Modern Context. The Case of Fishermen Community in Indonesia]. In: Makalah dalam Kongres Kebudayaan V di Bukit Tinggi Sumatra Barat, 20-23 Oktober 2003. Balai Kajian Sejarah dan Nilai Tradisional Makassar. Last accessed: July, 10, 2017.

[39] Hamid, A. R. (2011), Katalog dalam Terbitan (KDT): "Orang Buton-Suku Bangsa Bahari Indonesia" ("Butonese-Ethnic Group in Maritime Indonesia). Penerbit Ombak, Yogyakarta.

[40] Satria, A. (2015), Pengantar Sosiologi Masyarakat Pesisir [Introduction to the Sociology of Coastal Communities], Cetakan Pertama, Yayasan Pustaka Indonesia.

[41] UNCLOS (1982), United Nations Convention on the Law of the Sea, Montego Bay, Jamaica.

[42] Wiryawan, B, Khazali, Knight, M. (2005), Menuju kawasan konservasi laut berau Kalimantan Timur: Status Sumber Daya Pesisir dan Proses Pengembangan (Towards Regional Sea Conservation in Berau East Kalimantan) KKL, BKB TNC-WWF Mitra Pesisir/CRMP II USAID, Jakarta. Available online at: http://www.rareplanet.org/sites/rareplanet. org/files/Tugas_COMM_5311_ringkasan_eksekutif.pdf . Last accessed on 18 Dec 2018.

[43] Cahyadini, S., Setyawan, W. (2011), Informal Settlements and The Human Dimension Challenged in Coastal Areas, Indonesia. In: Proceedings of the Joint Conference of CIB W104 and W110: "Architecture in The Fourth Dimension - Methods and Practices for a Sustainable Building Stock”. Nov.15-17 2011. pp. 357362. Ball State University: Boston. Available online at: http://open-building.org/conference2011/web_ documents/A4D_Proceedings_web.pdf. Last accessed: Jan, 17, 2018 